\title{
Lanthanide(III) and Yttrium(III) Complexes of Benzimidazole-2-Acetic Acid: Synthesis, Characterisation and Effect of La(III) Complex on Germination of Wheat
}

\author{
Kalagouda B. Gudasi, ${ }^{1}$ Rashmi V. Shenoy, ${ }^{1}$ Ramesh S. Vadavi, ${ }^{1}$ Manjula S. Patil,, ${ }^{1}$ \\ Siddappa A. Patil, ${ }^{1}$ Rayappa R. Hanchinal, ${ }^{2}$ Srinivas A. Desai, ${ }^{2}$ and H. Lohithaswa ${ }^{2}$ \\ ${ }^{1}$ Department of Chemistry, Karnatak University, Dharwad 580 003, Karnataka, India \\ ${ }^{2}$ University of Agricultural Sciences, Dharwad 580 005, Karnataka, India
}

Received 4 April 2005; Revised 13 June 2005; Accepted 2 August 2005

The synthesis and characterisation of lanthanide(III) and yttrium(III) nitrate complexes of benzimidazole-2-acetic acid (HBIA) are reported. The complexes have been characterised by elemental analysis, molar conductance, magnetic studies, IR, ${ }^{1} \mathrm{H}$ NMR, UV-visible, EPR, and TG/DTA studies. They have the stoichiometry $\left[\operatorname{Ln}_{3}(\mathrm{BIA})_{2}\left(\mathrm{NO}_{3}\right)_{7}\left(\mathrm{H}_{2} \mathrm{O}\right)_{4}\right] \cdot 3 \mathrm{H}_{2} \mathrm{O}$ where $\mathrm{Ln}=\mathrm{La}(\mathrm{III}), \operatorname{Pr}(\mathrm{III})$, $\mathrm{Nd}(\mathrm{II}), \mathrm{Sm}(\mathrm{III}), \mathrm{Eu}(\mathrm{III}), \mathrm{Gd}(\mathrm{III}), \mathrm{Tb}(\mathrm{III}), \mathrm{Dy}(\mathrm{III})$, and Y(III). The effect of $\mathrm{La}(\mathrm{III})$ complex on germination, coleoptile, and root length of two local varieties of wheat DWR-195 and GW-349 for different treatment periods has been investigated. The complex was found to exhibit enhanced activity, compared to HBIA or metal salt alone at lower treatment periods.

Copyright (c) 2006 Kalagouda B. Gudasi et al. This is an open access article distributed under the Creative Commons Attribution License, which permits unrestricted use, distribution, and reproduction in any medium, provided the original work is properly cited.

\section{INTRODUCTION}

The use of rare earth elements (REE) in agriculture to promote the growth of plants is well known [1-4]. The utilization of REE containing fertilizers is widespread in China due to its rich REE resources. They are found to have nitrogenfixing capacity, to enhance seed germination, strengthen photosynthetic rate, to enhance respiration and activity of hydrolytic enzymes and plant hormones, and reduce water loss $[5,6]$. Chen et al [7] have reported the stimulation in growth of tobacco seedling treated with lanthanide. Enhancement in the germination of lanthanide-treated aged rice seeds has been reported by Fashui [8].

Heterocyclic compounds like indole-3-acetic acid and naphthyl-1-acetic acid are the plant auxins found to affect the growth of plants [8]. Especially benzimidazole-containing heterocyclic moieties have found extensive use in agriculture [9]. The lanthanide complexes of a few selected compounds have exhibited fungicidal and bactericidal activities including regulating the growth of plants [10-14].

It is known that chelation of metal ions with organic ligands acts synergistically to increase its effect [15].

Keeping this in view, the $\operatorname{Ln}(\mathrm{III})$ and Y(III) complexes of benzimidazole-2-acetic acid (HBIA) have been synthesized and characterised. $\mathrm{La}$ (III) complex of HBIA was used to carry out the germination study. The present experiment was conducted with a view to study the following.

(1) Effect of complex on germination, coleoptile, and root length of wheat.

(2) Comparative effect of complex, ligand, salt, and methanol on the above-mentioned factors compared to the control.

Lanthanides at high concentration are toxic whereas lower concentrations promote plant growth action, called the Hormesis effect [16]. Hence wheat seeds were treated with $10^{-6} \mathrm{M}$ solution for different treatment periods.

\section{EXPERIMENTAL}

\section{Chemicals and instruments}

Reagent grade chemicals were used without further purification. Ethyl cyanoacetate (S. D. Fine Chem Ltd, India) and ophenylenediamine (Koch Light Laboratories Ltd., England) was used. The metal contents of the complexes were determined by complexometric titrations against EDTA. Carbon, hydrogen, and nitrogen contents were determined by using a Carlo-Erba Strumentazione (Italy) CHN analyzer. Molar conductivities in DMSO $\left(10^{-3} \mathrm{M}\right)$ at room temperature 


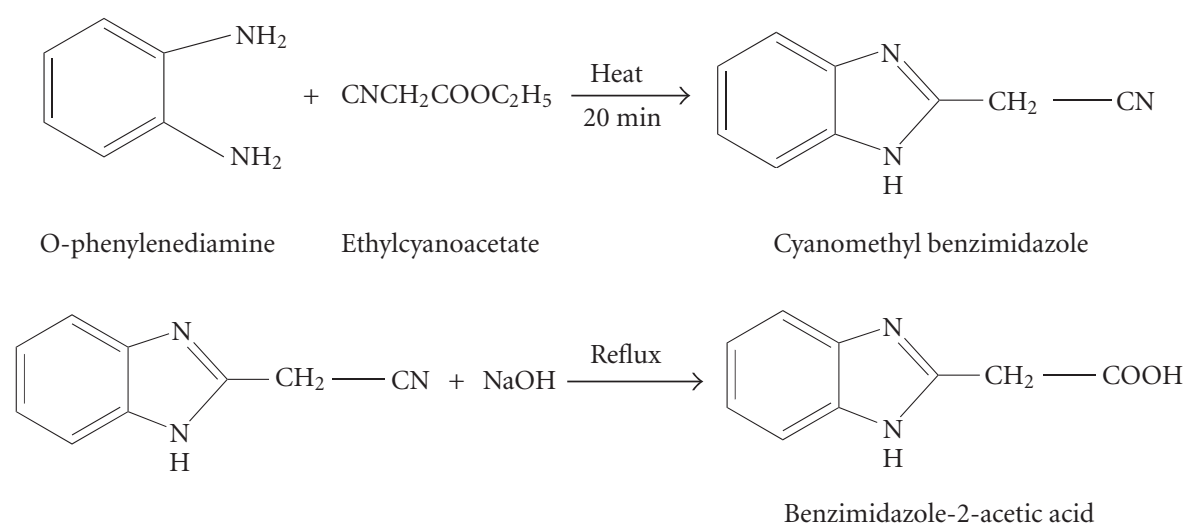

Scheme 1: Preparation of benzimidazole-2-acetic acid.

$\left(26^{\circ} \mathrm{C}\right)$ were measured using an Elico conductivity bridge having platinum electrodes. Magnetic moments were determined by a Faraday balance. The IR spectra of ligand and its metal complexes were recorded on a Nicolet 170 SX FT-IR spectrometer in the range $400-4000 \mathrm{~cm}^{-1}$ using $\mathrm{KBr}$ discs. The EPR spectrum of the Gd(III) complex was recorded on a Varian E-4X band spectrophotometer. ${ }^{1} \mathrm{H}$ NMR spectra were recorded on a Bruker Avance $300 \mathrm{MHz}$ NMR spectrometer using DMSO- $\mathrm{d}_{6}$ as solvent. UV-visible spectra were measured on a Hitachi 2001 spectrophotometer using dimethylsulfoxide (DMSO) as solvent. Thermogravimetry (TG) and differential thermal analysis (DTA) measurements were made in $\mathrm{N}_{2}$ atmosphere between 20 and $1000^{\circ} \mathrm{C}$ using a Perkin-Elmer (Pyris Diamond) analyzer. Lanthanide nitrates were prepared by dissolving the corresponding oxide (99.99\%, Indian Rare Earths Ltd, India) in $50 \% \mathrm{HNO}_{3}$, followed by the evaporation of the excess acid.

\section{Synthesis of ligand}

The ligand was synthesized according to literature method [17].

\section{(a) Preparation of cyanomethyl benzimidazole}

o-phenylenediamine (10 mmol, $10.0 \mathrm{~g})$ and ethylcyanoacetate $(15 \mathrm{mmol}, 17 \mathrm{~g})$ were placed in the reaction tube and heated in boiling aniline for 20 minutes. The residue was broken up and extracted with ether. The residue was recrystallised from hot water with the aid of norite and finally from alcohol and water (Scheme 1).

(i) Yield: $11 \mathrm{~g}(70 \%)$,

(ii) MP: $209.7-210.7^{\circ} \mathrm{C}$.

\section{(b) Alkaline hydrolysis}

2-cyanomethyl benzimidazole ( $10 \mathrm{mmol}, 1.57 \mathrm{~g})$ was added to $20 \mathrm{cc}$ of a water solution containing $1.2 \mathrm{~g}$ of $\mathrm{NaOH}$ and $3 \mathrm{cc}$ of ethanol and refluxed for 2 hours or until no more ammonia was evolved. The solution was then acidified with acetic acid.

(i) Yield: $1.65 \mathrm{~g}(95 \%)$,

(ii) $\mathrm{MP}: 116^{\circ} \mathrm{C}$ (with decarboxylation, solidification, and remelting at $176^{\circ} \mathrm{C}$ (2-methyl benzimidazole)).

\section{Synthesis of complexes}

The ligand was first converted into its sodium salt by refluxing $\mathrm{NaOH}$ ( $2 \mathrm{mmol}, 0.080 \mathrm{~g}$ ) and HBIA (2 mmol, $0.0352 \mathrm{~g}$ ) in $20 \mathrm{ml}$ methanol for half an hour. $\mathrm{Ln}\left(\mathrm{NO}_{3}\right)_{3}(1 \mathrm{mmol})$ dissolved in minimum amount of methanol was added and further refluxed for 3 hours. The solution was then concentrated to a small volume and the precipitate obtained was filtered, washed with water and ethanol, and air-dried.

(i) Yield: 75\%.

\section{MATERIALS AND METHODS}

\section{Procedure}

Two local varieties of wheat (DWR-195 and GW-349, developed at UAS, Dharwad) were selected for the experiment. The solution of compounds $\left(10^{-6} \mathrm{M}\right)$ was prepared in methanol due to its insolubility in water. The compounds to be tested consisted of $\mathrm{La}(\mathrm{BIA})$ complex, HBIA ligand, $\mathrm{La}\left(\mathrm{NO}_{3}\right)_{3}$, methanol, and water (control) assigned as groups $1,2,3,4$, and 5 , respectively. The periods of treatment varied from 2, 5, 8, and 11 minutes assigned as T1, T2, T3, and T4, respectively.

The seeds were soaked in the respective solutions for the above-mentioned time periods and then placed between germination papers $(46 \mathrm{~cm} \times 29 \mathrm{~cm}$ in size $)$ previously soaked with water in two rows. They were then rolled carefully ensuring no excess pressure was placed on seeds, wrapped in a sheet of polythene film to reduce surface evaporation, and placed in a germination chamber. On the fifth day after germination, the germination count was taken. Ten seedlings (out of 25 taken) were randomly selected and measured for 
TABLE 1: Effect of La(III) complex on germination of wheat (variety GW-349).

\begin{tabular}{l|cccc}
\hline \multirow{2}{*}{ Groups } & \multicolumn{3}{|c}{ Treatments } \\
\cline { 2 - 5 } & T1 $(2 \mathrm{~min})$ & T2 $(5 \mathrm{~min})$ & T3 $(8 \mathrm{~min})$ & T4 (11 min) \\
\hline Group1 La(III) complex & 98.66 & 97.33 & 96.66 & 96.66 \\
Group 2 (BIA ligand) & 95.0 & 94.0 & 93.0 & 91.33 \\
Group 3 La(NO$)_{3}$ salt & 94.0 & 95.0 & 91.33 & 89.66 \\
Group 4 methanol & 94.0 & 92.33 & 91.33 & 89.66 \\
Group 5 control (water) & 97.33 & 98.66 & 98.66 & 100 \\
\hline
\end{tabular}

TABLE 2: Effect of La(III) complex on germination of wheat (variety DWR-195).

\begin{tabular}{l|llll}
\hline \multirow{2}{*}{ Groups } & \multicolumn{4}{|c}{ Treatments } \\
\cline { 2 - 5 } & $\mathrm{T} 1$ & $\mathrm{~T} 2$ & $\mathrm{~T} 3$ & $\mathrm{~T} 4$ \\
\hline Group1 & 97.33 & 95.0 & 95.0 & 94.0 \\
Group 2 & 95.0 & 96.0 & 94.0 & 94.0 \\
Group 3 & 95.0 & 93.0 & 93.0 & 89.66 \\
Group 4 & 95.0 & 94.0 & 91.33 & 91.33 \\
Group 5 & 95.66 & 95.33 & 96.0 & 98.66 \\
\hline
\end{tabular}

TABLE 3: Effect of La(III) complex on root length (in $\mathrm{mm}$ ) of wheat (variety GW-349).

\begin{tabular}{l|cccc}
\hline \multirow{2}{*}{ Groups* } & \multicolumn{4}{|c}{ Treatments* } \\
\cline { 2 - 5 } & T1 & T2 & T3 & T4 \\
\hline Group1 & 134.86 & 126.83 & 110.26 & 120.66 \\
Group 2 & 116.56 & 116.03 & 111.93 & 110.56 \\
Group 3 & 114.83 & 107.93 & 101.96 & 105.46 \\
Group 4 & 111.50 & 114.70 & 100.80 & 104.0 \\
Group 5 & 113.36 & 115.80 & 123.83 & 123.23 \\
\hline
\end{tabular}

*Please refer to Table 1 for details of treatments and groups.

their coleoptile and root length. Three replications were carried out for each observation.

\section{Statistical analysis}

The statistical evaluation of the results was conducted with use of SPSS-(statistical package for social science; Windows version 6.0) packed program. One-way analysis of variance (ANOVA) was used to analyze the results. The level of statistical significance was set at $P<.05$.

\section{RESULTS AND DISCUSSION}

\section{Germination percentage}

In case of variety GW-349 (Table 1), there was no significant difference between all the groups at T1 and T2. In case of T3, groups 3 and 4 showed significant decrease in germination percentage $(\mathrm{GP})$ compared to the control $(P<.05)$. At T4, group 5 showed significant increase in GP compared to groups 2, 3, and 4. Group 1 showed significant increase in GP compared to groups 3 and 4 .
TABLE 4: Effect of La(III) complex on root length of wheat (in mm) (variety DWR-195).

\begin{tabular}{l|cccc}
\hline \multirow{2}{*}{ Groups* } & \multicolumn{4}{|c}{ Treatments* } \\
\cline { 2 - 5 } & $\mathrm{T} 1$ & $\mathrm{~T} 2$ & $\mathrm{~T} 3$ & $\mathrm{~T} 4$ \\
\hline Group1 & 138.70 & 135.03 & 125.10 & 135.66 \\
Group 2 & 153.86 & 132.30 & 123.0 & 101.80 \\
Group 3 & 121.96 & 124.56 & 123.76 & 123.46 \\
Group 4 & 129.16 & 127.56 & 126.23 & 121.66 \\
Group 5 & 129.0 & 123.53 & 122.86 & 131.83 \\
\hline
\end{tabular}

* Please refer to Table 1 for details of treatments and groups.

In case of variety DWR-195 (Table 2), at T1, T2, and T3 there was no significant difference in GP in case of all the groups. At T4, group 1 seeds showed significant increase in GP compared to group 5(control).

\section{Root length}

In case of variety GW-349 (Table 3), at T1, group 1 showed significant increase in root length (RL) compared to groups 2, 4, and 5(control). At T2, T3, and T4 there was no significant differences between the groups.

In case of variety DWR-195 (Table 4), at T1, T2, and T4, group 1 shows significant increase in RL compared to groups $2,3,4$, and 5(control), while at T3 group 1 does not show any significant differences between the groups.

\section{Shoot length}

In case of variety GW-349 (Table 5), group 1 showed increased shoot lengths (SL) compared to groups 2, 4, and 5 at T1, T2, and T3 while group 3 showed significant difference compared to group 1. At T2 and T3, group 1 showed increased SL compared to group 3. However, at T3 and T4, group 1 showed no significant increase in SL compared to control, and compared to group 2 at T4. Group 1 showed significant increase in SL compared to groups 3 and 4 at T4.

In case of variety DWR-195 (Table 6), group 1 showed significant increase in SL for the treatment periods T1, T2, T3, and T4 compared to groups 2, 3, 4, and control. However group 3 showed significant increase in SL compared to group 1 at T3 while at T4 there was no significant difference between group 1 and control. 
TABLE 5: Effect of La(III) complex on shoot length (in $\mathrm{mm}$ ) of wheat (variety GW-349).

\begin{tabular}{l|llll}
\hline \multirow{2}{*}{ Groups* } & \multicolumn{4}{|c}{ Treatments* } \\
\cline { 2 - 5 } & $\mathrm{T} 1$ & $\mathrm{~T} 2$ & $\mathrm{~T} 3$ & $\mathrm{~T} 4$ \\
\hline Group1 & 72.76 & 68.06 & 65.26 & 62.53 \\
Group 2 & 67.70 & 53.30 & 61.26 & 63.26 \\
Group 3 & 75.0 & 52.03 & 52.33 & 48.93 \\
Group 4 & 57.96 & 60.36 & 50.96 & 43.0 \\
Group 5 & 61.46 & 63.86 & 65.70 & 65.16 \\
\hline
\end{tabular}

* Please refer to Table 1 for details of treatments and groups.

TABLE 6: Effect of La(III) complex on shoot length (in mm) of wheat (variety DWR-195).

\begin{tabular}{l|cccc}
\hline \multirow{2}{*}{ Groups* } & \multicolumn{4}{|c}{ Treatments* } \\
\cline { 2 - 5 } & $\mathrm{T} 1$ & $\mathrm{~T} 2$ & $\mathrm{~T} 3$ & $\mathrm{~T} 4$ \\
\hline Group 1 & 76.0 & 69.36 & 64.63 & 61.76 \\
Group 2 & 60.4 & 58.60 & 53.63 & 50.33 \\
Group 3 & 58.33 & 61.80 & 71.10 & 42.23 \\
Group 4 & 57.83 & 56.73 & 52.53 & 53.43 \\
Group 5 & 55.03 & 61.33 & 52.30 & 62.20 \\
\hline
\end{tabular}

* Please refer to Table 1 for details of treatments and groups.

\section{General aspects}

The complexes are nonhygroscopic, off-white in color, and have $3: 2$ (M : L) stoichiometry (Table 7 ). The complexes are almost soluble in methanol, ethanol and completely soluble in DMF and DMSO whereas they are insoluble in acetone, chloroform, benzene, and ethyl acetate. The molar conductivity values of the complexes in $10^{-3} \mathrm{M}$ DMSO (Table 7) are in the range $4.4-9.6 \mathrm{Ohm}^{-1} \mathrm{~cm}^{2} \mathrm{~mol}^{-1}$ indicating their nonelectrolytic nature [18].

Magnetic moment values indicate the absence of metalmetal interaction and the noninvolvement of $4 \mathrm{f}$ electrons in bonding.

\section{Spectral analysis}

\section{Infrared}

The IR spectral data of HBIA and its Ln(III) complexes is given in Table 8 . In the free ligand, a broad band in the region $2525-3391 \mathrm{~cm}^{-1}$ is due to intramolecular hydrogen bonding between $\mathrm{OH}$ of carboxylic group and $\mathrm{C}=\mathrm{N}$ [19]. The bands at $1647 \mathrm{~cm}^{-1}$ and $1613 \mathrm{~cm}^{-1}$ are assigned to the $v(\mathrm{C}=\mathrm{O})$ and $\nu(\mathrm{C}=\mathrm{N})$ groups, respectively [19]. The $-\mathrm{NH}$ stretching frequency is observed at $3164 \mathrm{~cm}^{-1}$. An intense band observed at $1567 \mathrm{~cm}^{-1}$ is characteristic of 2-substituted benzimidazoles [20].

In the complexes, the $v \mathrm{NH}$ vibrations appear in the range $3048-3055 \mathrm{~cm}^{-1}$ and has a comparatively lower value compared to that for the free ligand. On complexation, the $\nu \mathrm{C}=\mathrm{O}$ frequency vanishes and is replaced by two bands be-
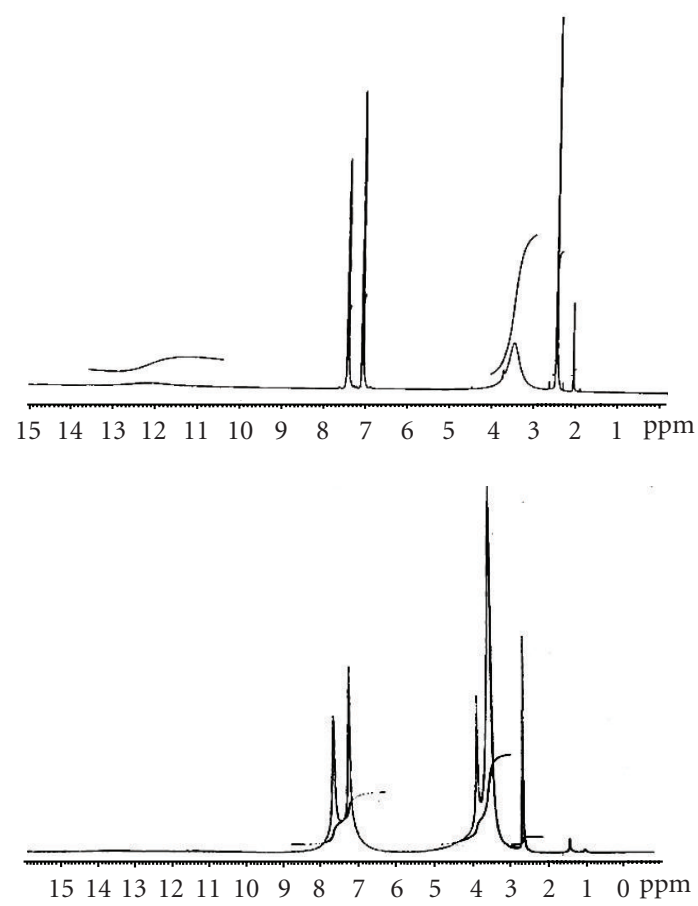

Figure 1: ${ }^{1} \mathrm{H}$ NMR spectra of HBIA and La(III) complex.

tween $1585-1591 \mathrm{~cm}^{-1}$ and $1431-1442 \mathrm{~cm}^{-1}$ assignable to $v_{\text {asy }}(\mathrm{COO})$ and $v_{\text {sym }}(\mathrm{COO})$, respectively. In the spectra of sodium salt of the ligand, the $v_{\text {asy }}(\mathrm{COO})$ and $v_{\text {sym }}(\mathrm{COO})$ occur at 1586 and $1441 \mathrm{~cm}^{-1}$, respectively.

In the present complexes, the difference between the $\nu_{\text {asym }}(\mathrm{COO})$ and $\nu_{\text {sym }}(\mathrm{COO})$ lies in the range $148-160 \mathrm{~cm}^{-1}$ whereas that of the sodium salt is $145 \mathrm{~cm}^{-1}$ indicating the coordination of carboxylate group to metal ions in bidentate bridging fashion $[21,22]$. The $\nu(C=N)$ band is shifted to lower frequency merging with the $v_{\text {asym }}(\mathrm{COO})$ band indicating its involvement in coordination.

The presence of coordinated nitrate groups is confirmed by the presence of six fundamental bands at 1313, 1525, 739, 708,998 , and $850 \mathrm{~cm}^{-1}$ which are assigned to $\nu_{1}, v_{4}, v_{3}, v_{5}, v_{2}$, and $v_{6}$, respectively. The difference between the two highest bands $v_{4}$ and $v_{1}$ lies in the range $206-216 \mathrm{~cm}^{-1}$, indicating the coordination of nitrate groups in bidentate or bidentate chelating fashion $[23,24]$.

A strong and broad absorption between $3375-3394 \mathrm{~cm}^{-1}$ in the complexes indicates the presence of water molecules.

\section{${ }^{1}$ H NMR spectra}

The ${ }^{1} \mathrm{H}$ NMR spectra of HBIA and its La(III) complex (Figure 1) was carried out in DMSO- $\mathrm{d}_{6}$. The proton assignments are given in Table 9.

A broad signal at $12.20 \mathrm{ppm}$ in the "free" ligand is ascribed to $-\mathrm{OH}$ of the carboxylic group which is intramolecularly hydrogen-bonded with the nitrogen of the benzimidazole moiety. Two quartets at 7.10 and $7.45 \mathrm{ppm}$ is due to four aromatic protons of the benzene moiety. A broad singlet at 
TABLE 7: Elemental analyses, magnetic moment, and conductance data of BIA and its Ln(III) complexes (calculated values are in parentheses).

\begin{tabular}{|c|c|c|c|c|c|c|}
\hline \multirow{2}{*}{ Compound } & \multicolumn{4}{|c|}{ Found (Calcd) (\%) } & \multirow{2}{*}{$\begin{array}{l}\text { Magnetic }^{\mathrm{a}} \\
\text { moment }\end{array}$} & \multirow{2}{*}{$\begin{array}{c}\text { Molar } \\
\text { conductivity }\end{array}$} \\
\hline & M & $\mathrm{C}$ & $\mathrm{H}$ & $\mathrm{N}$ & & \\
\hline (1) BIA & - & $\begin{array}{c}16.29 \\
(16.25)\end{array}$ & $\begin{array}{c}2.15 \\
(2.10)\end{array}$ & $\begin{array}{c}11.62 \\
(11.59)\end{array}$ & - & - \\
\hline (2) $\left[\mathrm{La}_{3}(\mathrm{BIA})_{2}\left(\mathrm{NO}_{3}\right)_{7}\left(\mathrm{H}_{2} \mathrm{O}\right)_{4}\right] \cdot 3 \mathrm{H}_{2} \mathrm{O}$ & $\begin{array}{c}31.65 \\
(31.70)\end{array}$ & $\begin{array}{c}16.24 \\
(16.18)\end{array}$ & $\begin{array}{c}2.11 \\
(2.09)\end{array}$ & $\begin{array}{l}11.58 \\
(1.53)\end{array}$ & dia & 7.6 \\
\hline (3) $\left[\mathrm{Pr}_{3}(\mathrm{BIA})_{2}\left(\mathrm{NO}_{3}\right)_{7}\left(\mathrm{H}_{2} \mathrm{O}\right)_{4}\right] \cdot 3 \mathrm{H}_{2} \mathrm{O}$ & $\begin{array}{c}32.14 \\
(32.10)\end{array}$ & $\begin{array}{c}16.16 \\
(16.06)\end{array}$ & $\begin{array}{c}2.16 \\
(2.08)\end{array}$ & $\begin{array}{c}11.40 \\
(11.45)\end{array}$ & 3.55 & 7.2 \\
\hline (4) $\left[\mathrm{Nd}_{3}(\mathrm{BIA})_{2}\left(\mathrm{NO}_{3}\right)_{7}\left(\mathrm{H}_{2} \mathrm{O}\right)_{4}\right] \cdot 3 \mathrm{H}_{2} \mathrm{O}$ & $\begin{array}{c}32.74 \\
(32.61)\end{array}$ & $\begin{array}{c}15.91 \\
(15.84)\end{array}$ & $\begin{array}{c}2.13 \\
(2.05)\end{array}$ & $\begin{array}{c}11.35 \\
(11.29)\end{array}$ & 3.61 & 8.3 \\
\hline (5) $\left[\mathrm{Sm}_{3}(\mathrm{BIA})_{2}\left(\mathrm{NO}_{3}\right)_{7}\left(\mathrm{H}_{2} \mathrm{O}\right)_{4}\right] \cdot 3 \mathrm{H}_{2} \mathrm{O}$ & $\begin{array}{c}33.42 \\
(33.53)\end{array}$ & $\begin{array}{c}15.85 \\
(15.79)\end{array}$ & $\begin{array}{c}2.01 \\
(2.04)\end{array}$ & $\begin{array}{c}11.19 \\
(11.25)\end{array}$ & 1.64 & 6.9 \\
\hline (6) $\left[\mathrm{Eu}_{3}(\mathrm{BIA})_{2}\left(\mathrm{NO}_{3}\right)_{7}\left(\mathrm{H}_{2} \mathrm{O}\right)_{4}\right] \cdot 3 \mathrm{H}_{2} \mathrm{O}$ & $\begin{array}{c}34.69 \\
(34.66)\end{array}$ & $\begin{array}{c}15.68 \\
(15.60)\end{array}$ & $\begin{array}{c}2.07 \\
(2.02)\end{array}$ & $\begin{array}{c}11.17 \\
(11.12)\end{array}$ & 3.40 & 7.7 \\
\hline (7) $\left[\mathrm{Gd}_{3}(\mathrm{BIA})_{2}\left(\mathrm{NO}_{3}\right)_{7}\left(\mathrm{H}_{2} \mathrm{O}\right)_{4}\right] \cdot 3 \mathrm{H}_{2} \mathrm{O}$ & $\begin{array}{c}34.46 \\
(34.54)\end{array}$ & $\begin{array}{c}15.66 \\
(15.55)\end{array}$ & $\begin{array}{c}2.06 \\
(2.01)\end{array}$ & $\begin{array}{c}11.13 \\
(11.08)\end{array}$ & 7.79 & 8.6 \\
\hline (8) $\left[\mathrm{Tb}_{3}(\mathrm{BIA})_{2}\left(\mathrm{NO}_{3}\right)_{7}\left(\mathrm{H}_{2} \mathrm{O}\right)_{4}\right] \cdot 3 \mathrm{H}_{2} \mathrm{O}$ & $\begin{array}{c}34.67 \\
(34.77)\end{array}$ & $\begin{array}{c}15.52 \\
(15.43)\end{array}$ & $\begin{array}{l}2.01 \\
(2.0)\end{array}$ & $\begin{array}{l}11.12 \\
(11.0)\end{array}$ & 9.82 & 4.4 \\
\hline (9) $\left[\mathrm{Dy}_{3}(\mathrm{BIA})_{2}\left(\mathrm{NO}_{3}\right)_{7}\left(\mathrm{H}_{2} \mathrm{O}\right)_{4}\right] \cdot 3 \mathrm{H}_{2} \mathrm{O}$ & $\begin{array}{c}35.21 \\
(35.28)\end{array}$ & $\begin{array}{c}18.00 \\
(18.32)\end{array}$ & $\begin{array}{c}2.25 \\
(2.37)\end{array}$ & $\begin{array}{c}13.17 \\
(13.06)\end{array}$ & 10.30 & 9.6 \\
\hline (10) $\left[\mathrm{Y}_{3}(\mathrm{BIA})_{2}\left(\mathrm{NO}_{3}\right)_{7}\left(\mathrm{H}_{2} \mathrm{O}\right)_{4}\right] \cdot 3 \mathrm{H}_{2} \mathrm{O}$ & $\begin{array}{c}23.01 \\
(22.97)\end{array}$ & $\begin{array}{c}47.16 \\
(47.06)\end{array}$ & $\begin{array}{c}3.49 \\
(3.50)\end{array}$ & $\begin{array}{c}18.70 \\
(18.78)\end{array}$ & dia & 8.0 \\
\hline
\end{tabular}

${ }^{\mathrm{a} B M} \cdot{ }^{\mathrm{b}} \mathrm{Ohm}^{-1} \mathrm{~cm}^{2} \mathrm{~mol}^{-1}$.

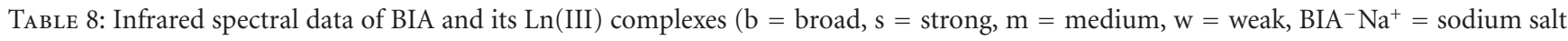
of ligand).

\begin{tabular}{|c|c|c|c|c|c|c|c|c|c|c|c|c|}
\hline Compound & $\nu \mathrm{O}_{\mathrm{H}}$ & $\nu \mathrm{NH}$ & $\nu \mathrm{C}=\mathrm{O}$ & $v_{\text {asy }} \mathrm{COO}$ & $v_{\text {sym }} \mathrm{COO}$ & $\Delta v=v_{\text {asy }} \mathrm{COO}-v_{\text {sym }} \mathrm{COO}$ & $v_{4}$ & $v_{1}$ & $v_{3}$ & $\nu_{5}$ & $v_{6}$ & $v_{2}$ \\
\hline$\overline{\mathrm{BIA}}$ & 3391 & $3164 \mathrm{~s}$ & $1647 \mathrm{~s}$ & - & - & - & - & - & - & - & - & - \\
\hline$(\mathrm{BIA}) \mathrm{Na}$ & - & $3164 s$ & - & $1586 s$ & $1441 s$ & 145 & - & - & - & - & - & - \\
\hline (2) & $3388 b$ & $3055 \mathrm{~s}$ & - & $1591 \mathrm{sb}$ & $1431 \mathrm{~s}$ & 160 & 1525 & 1313 & 739 & 708 & 858 & 998 \\
\hline (3) & $3388 b$ & $3048 s$ & - & $1591 \mathrm{sb}$ & $1431 \mathrm{~s}$ & 160 & 1525 & 1313 & 745 & 705 & 850 & 997 \\
\hline (4) & $3388 b$ & $3049 s$ & - & $1591 \mathrm{sb}$ & $1437 \mathrm{~s}$ & 154 & 1525 & 1319 & 745 & 695 & 850 & 998 \\
\hline (5) & $3375 b$ & $3048 s$ & - & $1591 \mathrm{sb}$ & $1431 \mathrm{~s}$ & 160 & 1535 & 1319 & 745 & 707 & 850 & 998 \\
\hline (6) & $3388 b$ & $3055 \mathrm{~s}$ & - & $1591 \mathrm{sb}$ & $1437 \mathrm{~s}$ & 154 & 1529 & 1313 & 739 & 702 & 856 & 998 \\
\hline (7) & $3394 b$ & $3054 \mathrm{~s}$ & - & $1597 \mathrm{sb}$ & $1442 \mathrm{~s}$ & 155 & 1528 & 1316 & 742 & 707 & 850 & 999 \\
\hline (8) & $3394 b$ & $3054 \mathrm{~s}$ & - & $1591 \mathrm{sb}$ & $1442 \mathrm{~s}$ & 149 & 1528 & 1319 & 745 & 701 & 850 & 996 \\
\hline (9) & $3376 b$ & $3055 \mathrm{~s}$ & - & $1585 \mathrm{sb}$ & $1437 \mathrm{~s}$ & 148 & 1528 & 1320 & 745 & 702 & 856 & 996 \\
\hline (10) & $3388 b$ & $3055 \mathrm{~s}$ & - & $1597 \mathrm{sb}$ & $1437 \mathrm{~s}$ & 160 & 1529 & 1320 & 745 & 702 & 856 & 998 \\
\hline
\end{tabular}

$3.5 \mathrm{ppm}$ is due to NH. A sharp singlet at $2.5 \mathrm{ppm}$ is assignable to two protons of the $-\mathrm{CH}_{2}$ group which also overlaps with the DMSO peak.

On complexation, the $-\mathrm{OH}$ signal disappears completely indicating the breakdown of intramolecular hydrogen bonding along with ligation of $\mathrm{COO}-$ to metal ion. The downfield shift of the $-\mathrm{NH}$ signal from 3.5-3.7 ppm indicates the involvement of $v(\mathrm{C}=\mathrm{N})$ in coordination with the metal ion.
The $-\mathrm{CH}_{2}$ proton undergoes a very slight upfield shift to $2.48 \mathrm{ppm}$. The aromatic protons appear in the region 7.077.47 ppm.

\section{UV-visible spectra}

The electronic spectra of HBIA displays three absorption bands at 276, 270, and $257 \mathrm{~nm}$ which are assigned to the 
TABLE 9: ${ }^{1} \mathrm{H}$ NMR spectral data (ppm) of BIA and its La(III) complex ( $\mathrm{b}=$ broad; $\mathrm{q}=$ quartet; $\mathrm{d}=$ doublet; $\mathrm{s}=$ singlet $)$.

\begin{tabular}{ccc}
\hline Proton & BIA & La(III) complex \\
\hline$-\mathrm{OH}$ & $12.20(\mathrm{~s}, \mathrm{br})$ & - \\
$-\mathrm{NH}$ & $3.5(\mathrm{~s}, \mathrm{br})$ & $3.70(\mathrm{~s})$ \\
$-\mathrm{CH}_{2}$ & $2.5(\mathrm{~s})$ & $2.48(\mathrm{~s})$ \\
Aromatic protons & $7.45(\mathrm{q}, 2 \mathrm{H})$ & $7.47(\mathrm{~d}, 2 \mathrm{H})$ \\
- & $7.10(\mathrm{q}, 2 \mathrm{H})$ & $7.07(\mathrm{~d}, 2 \mathrm{H})$ \\
\hline
\end{tabular}

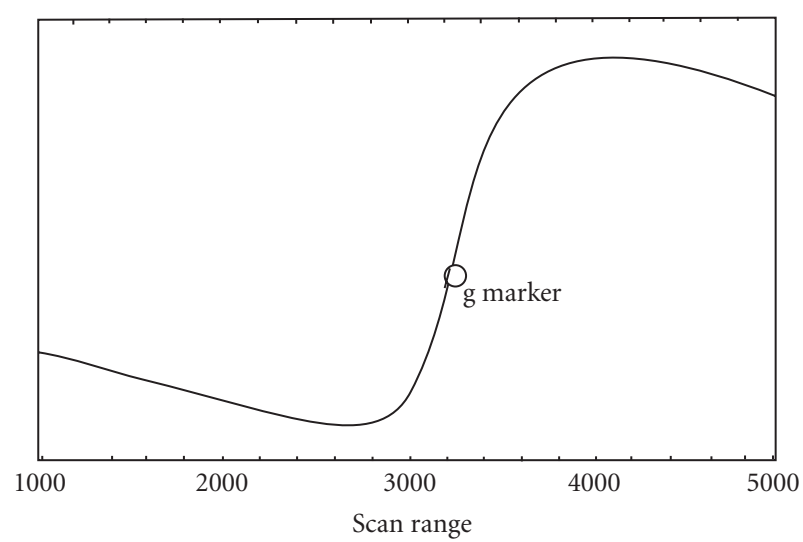

FIGURE 2: EPR spectrum of $\left[\mathrm{Gd}_{3}(\mathrm{BIA})_{2}\left(\mathrm{NO}_{3}\right)_{7}\left(\mathrm{H}_{2} \mathrm{O}\right)_{4}\right] \cdot 3 \mathrm{H}_{2} \mathrm{O}$ (at RT).

$\pi-\pi^{*}$ transitions. The electronic spectra of the complexes are similar to that of ligand except for a very slight shift towards lower frequency. A comparison of the transitions of the complexes with their corresponding aquo ions has been made (Table 10). This data clearly indicates that the energy of f-f transitions in the complexes is slightly reduced from the corresponding aquo ions, due to perhaps covalent interaction of 4f orbitals with vacant ligand orbitals or increased nuclear shielding of f-orbitals due to slight L-M electron transfer [25]. The nephelauxetic ratio $(\beta)$, bonding parameter $\left(b^{1 / 2}\right)$, Sinha's covalency parameter $(\delta \%)$, and angular covalency $(\eta)$ for the $\operatorname{Pr}(\mathrm{III})$ and $\mathrm{Nd}(\mathrm{III})$ complexes have been calculated [26-29].

The Sinha parameter $(\delta)$ is taken as a measure of covalency and is given by

$$
\delta(\%)=\frac{1-\beta_{\mathrm{av}}}{\beta_{\mathrm{av}}} \times 100,
$$

where $\beta_{\text {av }}$ is the average value of the ratio of $\nu_{\text {complex }} / \nu_{\text {aquo }}$.

The bonding parameter $\left(b^{1 / 2}\right)$, the magnitude of which suggests the comparative involvement of the $4 \mathrm{f}$ orbitals in metal-ligand bonding, is related to the nephelauxetic ratio $\beta$ and is given by the expression

$$
b^{1 / 2}=\left[\frac{1-\beta_{\mathrm{av}}}{2}\right]^{1 / 2} .
$$

$\delta$ values are less than one whereas the remaining values are positive indicating the interaction between the metal salts and ligand is mainly electrostatic.

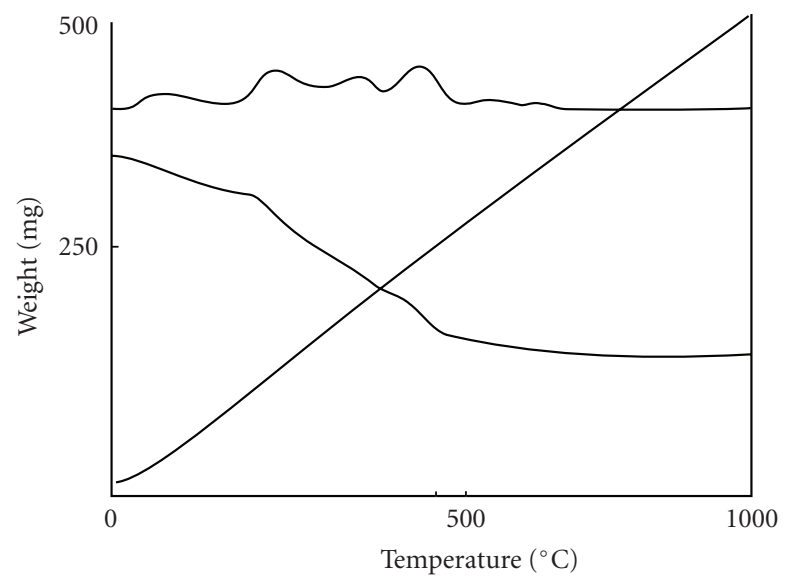

Figure 3: TG/DTA thermogram of $\left[\mathrm{Dy}_{3}(\mathrm{BIA})_{2}\left(\mathrm{NO}_{3}\right)_{7}\left(\mathrm{H}_{2} \mathrm{O}\right)_{4}\right]$. $3 \mathrm{H}_{2} \mathrm{O}$ complex.

\section{EPR spectra}

The EPR spectra of the Gd(III) complex (Figure 2) showed broad resonance peaks with $g=1.99$ (at RT) and 1.97 (at LNT). Similar g values and line widths (at both RT and LNT) indicate that line widths are independent of temperature [30]. It is observed that fine structure, as a consequence of Gd(III) zero-field splitting is lacking. The broad peaks obtained indicate that the Gd(III) complex is located in a rather disordered environment. Thus the spectrum is an average overall possible realization of the crystal field, which can be influenced by distribution of hydrogen bonds. Random H-bonds between water molecules and complex induce small distortions, which lead to line broadenings. This phenomenon called strain, more specifically g-strain for the gtensor distribution and D-strain for the ZFS (zero-field splitting) distribution, leads to broad asymmetric EPR line shapes $[31,32]$.

\section{Thermal analysis}

The TG/DTA study of a representative Dy(III) complex (Figure 3) was determined in nitrogen atmosphere up to $1000^{\circ} \mathrm{C}$ using a heating rate of $10^{\circ} \mathrm{C} / \mathrm{min}$.

The weight loss of $3.64 \%$ on TG curve between $29-79^{\circ} \mathrm{C}$ reveals the loss of three-lattice-held water molecules, which is in agreement with the calculated values of 3.85\%. The next weight loss of $5.09 \%$ between $80-150^{\circ} \mathrm{C}$ agrees (5.14\%) with the loss of four coordinated water molecules. A weight loss corresponds to the loss of a ligand molecule and four coordinated nitrate molecules (calc: $30.27 \%$ ), in the temperature range $280-540^{\circ} \mathrm{C}$. Above $500^{\circ} \mathrm{C}$ there is a plateau, which corresponds to the formation of stable $\mathrm{Dy}_{2} \mathrm{O}_{3}$. The metal percentage obtained is $34.78 \%$, which agrees well with calculated value $(34.83 \%)$ and is within the experimental error.

The tentative structure was arrived at on the basis of the various spectral studies and is shown in Figure 4. 
TABLE 10: Electronic spectral data of few Ln(III) complexes of BIA.

\begin{tabular}{|c|c|c|c|c|c|}
\hline Complex & Assignments & $\begin{array}{c}\lambda_{\max } \text { of } \mathrm{Ln}^{+3} \\
\operatorname{ion}\left(\mathrm{cm}^{-1}\right)\end{array}$ & $\begin{array}{c}\lambda_{\max } \text { of complex } \\
\left(\mathrm{cm}^{-1}\right)\end{array}$ & $\beta$ & Other parameters \\
\hline \multirow{4}{*}{ 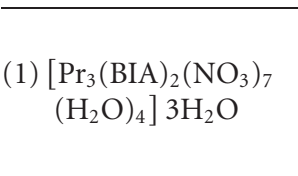 } & ${ }^{3} \mathrm{H}_{4--}{ }^{3} \mathrm{P}_{2}$ & 22512 & 22502 & 0.99955 & \multirow{4}{*}{$\begin{array}{l}\delta=0.10511 \\
\mathrm{~b}^{1 / 2}=0.02291 \\
\eta=0.03242\end{array}$} \\
\hline & $-{ }^{3} \mathrm{P}_{0}$ & 20716 & 20678 & 0.99816 & \\
\hline & $--^{1} D_{2}$ & 16854 & 16840 & 0.99916 & \\
\hline & & & & 0.99895 & \\
\hline \multirow{5}{*}{$\begin{array}{c}(2)\left[\mathrm{Nd}_{3}(\mathrm{BIA})_{2}\left(\mathrm{NO}_{3}\right)_{7}\right. \\
\left.\left(\mathrm{H}_{2} \mathrm{O}\right)_{4}\right] 3 \mathrm{H}_{2} \mathrm{O}\end{array}$} & ${ }^{4} \mathrm{I}_{9 / 2}-{ }^{-2} \mathrm{G}_{9 / 2}$ & 19747 & 19565 & 0.99078 & \multirow{5}{*}{$\begin{array}{l}\delta=0.70797 \\
\mathrm{~b}^{1 / 2}=0.0592 \\
\eta=0.08414\end{array}$} \\
\hline &.$--{ }^{4} G_{5 / 2}$ & 17253 & 17182 & 0.99588 & \\
\hline & $-{ }^{4} \mathrm{~F}_{9 / 2}$ & 14594 & 14450 & 0.99013 & \\
\hline & \multirow{2}{*}{$--{ }^{4} \mathrm{~F}_{5 / 2}$} & \multirow[t]{2}{*}{12853} & \multirow[t]{2}{*}{12790} & 0.99509 & \\
\hline & & & & 0.99297 & \\
\hline
\end{tabular}

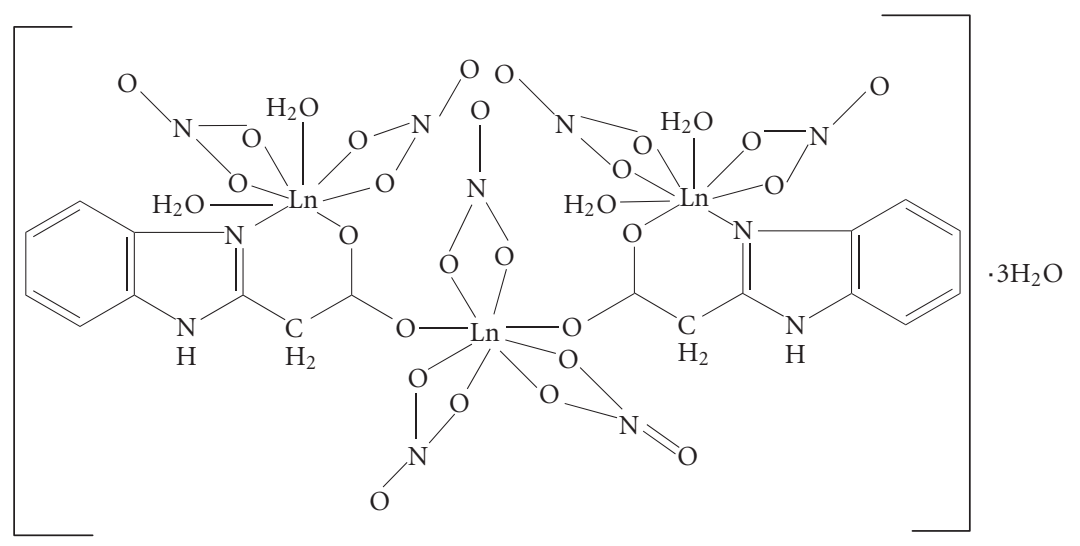

FIgURE 4

\section{CONCLUSION}

The results obtained in the present study indicate that in both the varieties, germination percentage of water-treated seeds and complex treated seeds was not significantly different at lower treatment periods of 2, 5, and 8 minutes indicating germination is not affected by the treatments. In case of root length the root lengths of complex-treated seeds, at lower treatment period of 2 minutes, were significantly higher than the water-treated ones.

In case of shoot length, in both the varieties the complextreated seeds showed significant increase in shoot length compared to the water-treated ones at lower treatment periods of 2,5 , and 8 minutes.

In all the cases, the complex-treated seeds showed significant increase compared to those treated with ligand and metal salt alone.

From this, it is concluded that the $\mathrm{La}\left(\mathrm{NO}_{3}\right)_{3}$ salt or HBIA alone is not effective but the complex acts synergistically to enhance the effect of the two. In case of period of treatments, lower treatment period ( 2 minutes) was found to be most effective in all the cases.

Hence lanthanide complexes of benzimidazoles and other auxins may prove to be very good plant growth promoters.

\section{ACKNOWLEDGMENTS}

Thanks are due to SIF, IISc, Bangalore, CDRI, Lucknow, IIT, Bombay, and USIC, Karnatak University, Dharwad, for recording NMR, Mass, EPR, and UV visible spectra, respectively. Thanks are due to Seed Department, University of Agricultural Sciences, Dharwad, for providing facilities for carrying out the germination experiments.

\section{REFERENCES}

[1] Wang G, Miao X, Li J. Faming Zhuanli Shenqing Gongkai Shuomingshu. CN, 267, 455 (Cl A01 N59/00), 27 September, 2000, Appl. 2, 000103, 926, 9 March, 2000, 5 pp(Ch).

[2] Lu K, Chang Z, Chen B, Guo D, Zheng J, Wang K. Hormonelike effect of rare earth elements on plant. Beijing Yi Ke Da Xue Хиe Bao. 1997;29(4):289.

[3] He Y-W, Loh C-S. Cerium and lanthanum promote floral initiation and reproductive growth of Arabidopsis thaliana. Plant Science. 2000;159(1):117-124.

[4] Guo BS. Rare Earth Elements in Agriculture. Beijing, China: Agriculture Science and Technology Press; 1998.

[5] Hong F, Fang N, Zhao G. Studies of physiological and biochemical bases of lanthanum on increasing seed vigor of rice. Xibei Zhiuru Xuebao. 1999;19(4):585.

[6] Wen B, Yuan DA, Shan XQ, Li FL, Zhang SZ. The influence of rare earth element fertilizer application on the distribution 
and bioaccumulation of rare earth elements in plants under field conditions. Chemical Speciation and Bioavailability. 2001;13(2):39-48.

[7] Chen WJ, Tao Y, Gu YH, Zhao GW. Effect of lanthanide chloride on photosynthesis and dry matter accumulation in tobacco seedlings. Biological Trace Element Research. 2001;79(2):169-176.

[8] Fashui H. Study on the mechanism of cerium nitrate effects on germination of aged rice seed. Biological Trace Element Research. 2002;87(1-3):191-200.

[9] Huo W, Jian F, Zhengzhi Z. Effect of auxin hormone lanthanide complexes on the growth of wheat coleoptile. Biological Trace Element Research. 1998;64(1-3):27-35.

[10] Kukalenko SS, Bovykin BA, Shestakova SI, Omel'chenko AM. Metal-containing complexes of lactams, imidazoles, and benzimidazoles and their biological activity. Russian Chemical Reviews. 1985;54(7):676-689.

[11] Huang J, Yang Y, Yuan C. Effect of coordination complexes of rare earth chlorides with imidazole on soil microenvironment. Xibei Daxue Xuebao Ziran Kexueban. 1998;28(3):259.

[12] Yang L, Wu J, Xin J. Synthesis and characterization and EXAFS of new rare earth complexes. Ниа Хие Хие Вао. 1996;54(4): 374.

[13] He F, Wang L, Chen Z, Wu J, Wang Q. Study of ternary complexes of lanthanide metals, IV. Synthesis, characterization and bioactivity of lanthanide ternary complexes containing indole3-propionate and phenanthroline. Synthesis and Reactivity in Inorganic and Metal-Organic Chemistry. 1994;24(4):575.

[14] Li Z. Studies on rare-earth complexes of mixed amino acids and its application. Huaxue Tongbao. 1994;1:21.

[15] Cavanagh F. Analytical Microbiology. New York, NY: Academic Press, Kavanagh F ed.; 1963.

[16] Copeland RAB, Day AR. The preparation and reactions of 2benzimidazolecarboxylic acid and 2-benzimidazoleacetic acid. Journal of the American Chemical Society. 1943;65(6):10721075.

[17] Geary WJ. The use of conductivity measurements in organic solvents for the characterisation of coordination compounds. Coordination Chemistry Reviews. 1971;7(1):81-122.

[18] Morgan KJ. The infrared spectra of some simple benzimidazoles. Journal of the Chemical Society (Resumed). 1961:23432347.

[19] Rabiger JD, Jouillie MM. Ionization constants and ultraviolet and infrared spectra of some substituted benzimidazoles. Journal of Organic Chemistry. 1964;29(2):476-482.

[20] Jaffé HH. Correlation of Hammett's $\sigma$-values with electron densities calculated by molecular orbital theory. The Journal of Chemical Physics. 1952;20(2):279-284.

[21] Nakamoto K. Infrared and Raman Spectra of Inorganic and Coordination Compounds. 5th ed. New York, NY: John Wiley \& Sons; 1997.

[22] Deacon GB, Phillips RJ. Relationships between the carbonoxygen stretching frequencies of carboxylato complexes and the type of carboxylate coordination. Coordination Chemistry Reviews. 1980;33(3):227-250.

[23] Gatehouse BM, Livingstone SE, Nyholm RS. Infrared spectra of some nitrato-coordination complexes. Journal of the Chemical Society (Resumed). 1957:4222-4225.

[24] Curtis NF, Curtis YM. Some nitrato-amine nickel(II) compounds with monodentate and bidentate nitrate ions. Inorganic Chemistry. 1965;4(6):804-809.

[25] Jorgenson CK. Vibrational and solvent effects on an intra sub shell transition of Osmium(IV)hexachloro ions. Acta Chemica Scandinavica. 1962;16:793-798.
[26] Henrie DE, Choppin GR. Environmental effects on $f-f$ transitions. II. "Hypersensitivity" in some complexes of trivalent neodymium. The Journal of Chemical Physics. 1968;49(2):477481.

[27] Sinha SP. Spectroscopic investigations of some neodymium complexes. Spectrochimica Acta. 1966;22(1):57-62.

[28] Jorgenson CK. The nephelauxetic series, Progress in Inorganic Chemistry. New York, NY: Interscience publishers, Division of John Wiley, Cotton FA ed.; 1962; 4.

[29] Messimeri A, Raptopoulou CP, Nastopoulos V, Terzis A, Perlepes SP, Papadimitriou C. Synthesis and physical studies of lanthanide(III) complexes of N,N-bis(2-hydroxyethyl)glycinate (bicinate, $\mathrm{bicH}_{2}^{-}$): molecular and crystal structure of $\left[\mathrm{Gd}\left(\mathrm{O}_{2} \mathrm{CMe}\right)\left(\mathrm{bicH}_{2}\right)(\right.$ phen $\left.)\left(\mathrm{H}_{2} \mathrm{O}\right)\right]\left(\mathrm{CIO}_{4}\right)$. phen. $3 \mathrm{H}_{2} \mathrm{O}$ (phen=1,10-phenanthroline). Inorganica Chimica Acta. 2002;336:8-18.

[30] Ramirez FD, Sosa-Torres ME, Castro M, Basurto-Uribe E, Zamorano-Ullao R, Rio-Portillo FD. Synthesis, 1H, 13C NMR and magnetic studies of the homodinuclear lanthanide(III) polymeric compounds formed with the 1,5,9,13-tetraazacyclohexadecane ligand. Journal of Coordination Chemistry. 1997;41:303-326.

[31] Bencini A, Benelli C, Caneschi A, Carlin RL, Dei A, Gatteschi D. Crystal and molecular structure of and magnetic coupling in two complexes containing gadolinium(III) and copper(II) ions. Journal of the American Chemical Society. 1985;107(26):8128-8136.

[32] George GN, Prince RC, Bare RE. Electron paramagnetic resonance spectroscopy of the iron-molybdenum cofactor of Clostridium pasteurianum nitrogenase. Inorganic Chemistry. 1996;35(2):434-438. 


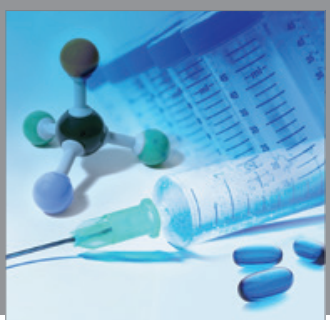

International Journal of

Medicinal Chemistry

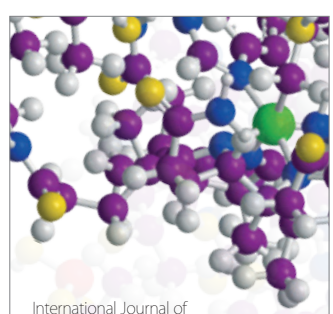

Carbohydrate Chemistry

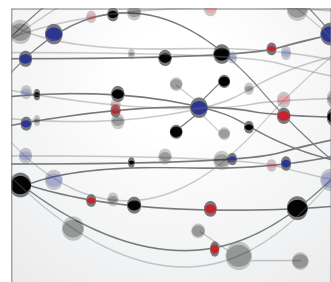

The Scientific World Journal
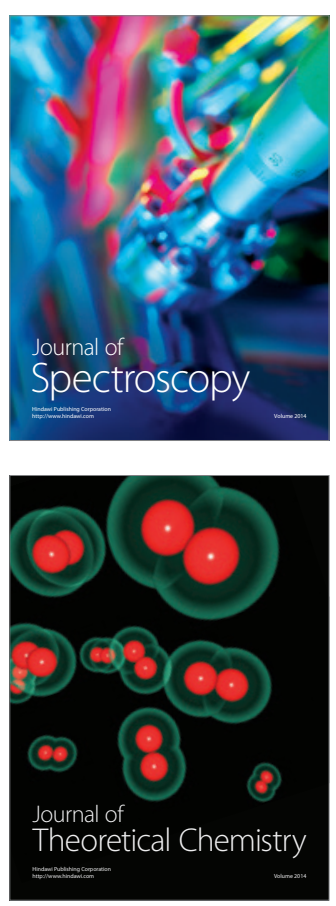
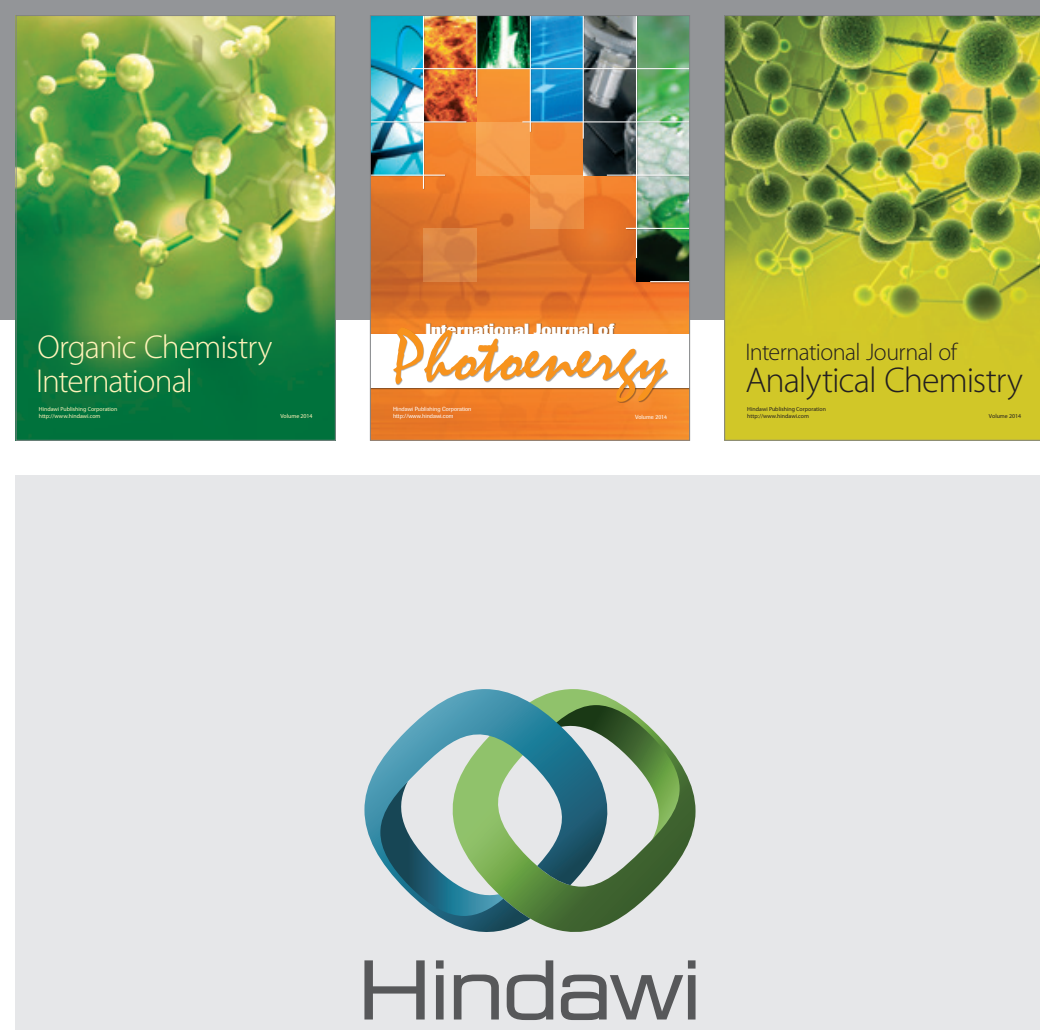

Submit your manuscripts at

http://www.hindawi.com
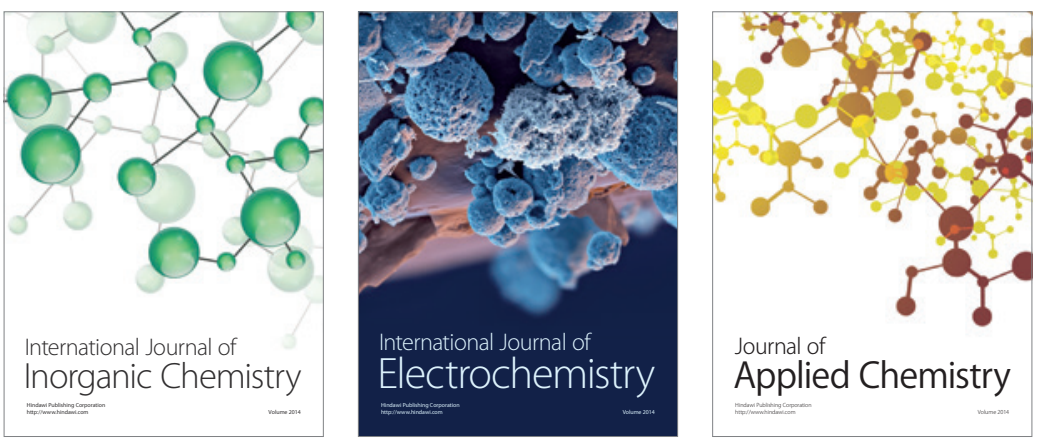

Journal of

Applied Chemistry
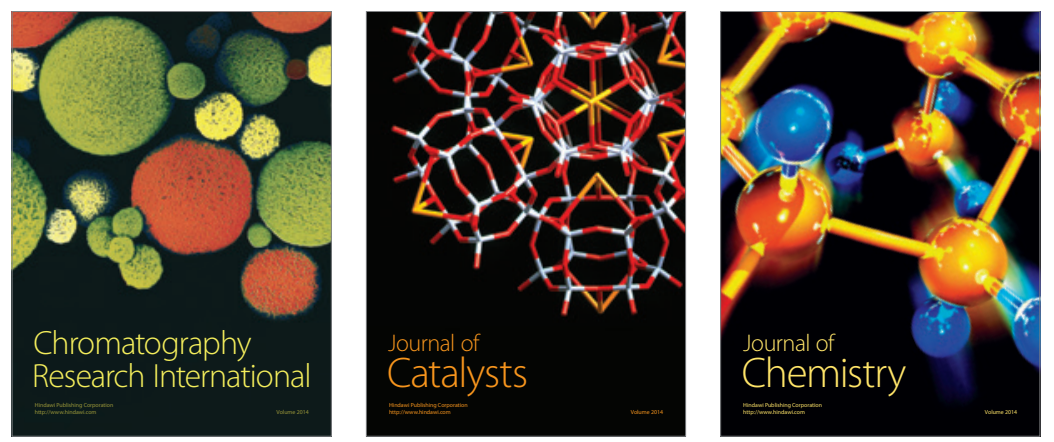
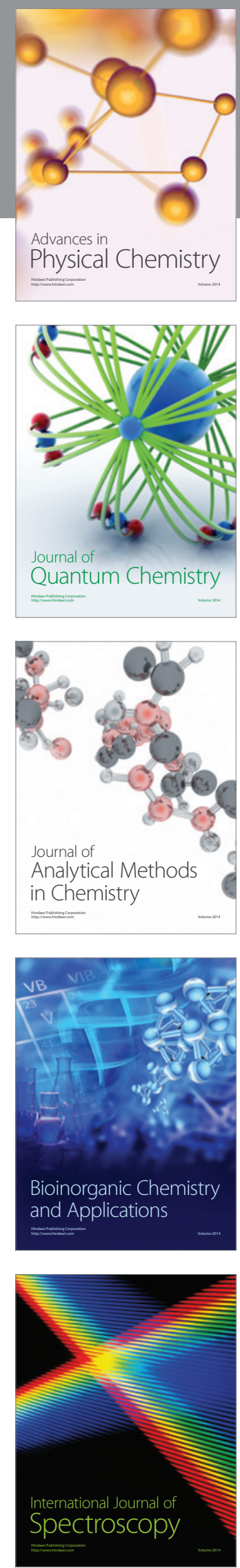